\title{
STUDIES ON MICROBIOLOGICAL QUALITY OF SPROUTS OF MUNG BEAN (VIGNA RADIATE L.)
}

\author{
Shilpi Chauhan ${ }^{1}$, Ankit Saini ${ }^{2}$, Devendra Pratap Singh**3 ${ }^{3}$ Umesh Dhaked $^{3}$, Poonam Gupta ${ }^{1}$ \\ ${ }^{1}$ Krishna College of Science and Technology, Bijnor, India \\ ${ }^{2}$ Krishna College of Pharmacy, Bijnor, India \\ ${ }^{3}$ Bhagwant Institute of Pharmacy, Muzaffarnagar, India \\ *Corresponding Author's Email: mdps1341619@gmail.com
}

\begin{abstract}
ABSRACT
Sprouts are now well known for their high nutritive value and digestibility. They are rich in enzymes, bioavailable vitamins, minerals, amino acids and fibers. Sprouts are low in fat and calories, being rich in nutrients and known to promote health, sprouts now days are available in most of the grocery stalls. Survey of sprouted seeds available at retail venders has shown the presence of pathogenic bacteria like E. coli 0157, Salmonella and Listeria monocytogens, which is of concern for health conscious public. In the present study an attempt has been made to identify and examine the microorganisms present in seed sprouts of mung bean.
\end{abstract}

Key-Words: Mung Bean Sprouts, Morphological Identification, Biochemical Characteristics.

\section{INTRODUCTION}

Sprouting is the practice of germinating seeds to be eaten either raw or cooked. They are a convenient way to have fresh vegetables for salads, in any season and can be germinated at home or produced industrially. Sprouts are believed to be highly nutritious and rich in enzymes which promote good health. Sprouts, including mung beans and alfalfa sprouts, have become a common food item in grocery stores, salad bars around the world. Sprouts are low in calories and fat and provide substantial amounts of key nutrients, such as vitamins, minerals, proteins, enzymes, folate, and fiber. ${ }^{1,2,3}$

Chavan and Kadam (1989) have described importance of sprouts as, "The desirable nutritional changes that occur during sprouting are mainly due to the breakdown of complex compounds into a more simple form, transformation into essential constituents and breakdown of nutritionally undesirable constituents that are easy to digest." ${ }^{4}$ A large number of food borne disease outbreaks reported world over have been found to be linked to sprouts. In most instances, the illnesses were caused by either Escherichia coli O157:H7 or Salmonella bacteria. Anyone who eats raw sprouts or lightly cooked mung bean sprouts is at risk for exposure to Escherichia coli $\mathrm{O} 157: \mathrm{H7}$ or Salmonella bacteria. ${ }^{5}$

The consumption of raw sprouts has become the focus of increasing concern during the past decade. Despite increased awareness and guidelines set forth by the Food and Drug Administration (FDA), food borne disease outbreaks linked to sprouts have continued. $6,7, \mathbf{8}$ Contamination of sprouts is generally thought to arise from contaminated seed. ${ }^{\mathbf{6 , 9}, \mathbf{1 0}}$ The one method is disinfecting the seeds that kill bacteria but that still allows the seeds to germinate to produce sprouts. Further some of the consumers do not want chemicals to be used to disinfect the seeds. Thus the only alternate available is to either control the contamination of seeds meant for consumption as sprouts or restrict the growth of pathogens during sprouting. Therefore the present study was undertaken to determine the microbiological quality of sprouts prepared in the laboratory.

\section{OBJECTIVES}

The primary objectives of the work presented here were

(i) To determine the number of microorganisms associated with mung bean sprouts prepared under laboratory conditions

(ii) To characterize and identify the microorganisms associated with sprouts.

\section{MATERIAL AND METHODS}

The present study entitled "Studies on microbiological quality of sprouts of Mung Bean (Vigna radiata) was carried out in Department of Microbiology, Sardar Bhagwan Singh Post Graduate Institute of Biomedical Sciences and Research, Balawala, Dehradun.

\section{Collection of Sample}

Two seed samples of mung bean were purchased from local market from two different retail shops.

\section{Seed Sprouting}

Each type of seeds $(5.0 \mathrm{~g})$ were placed in a sterile petri plate containing Whatmann No. 113 (qualitative wet strengthen) filter paper saturated with sterilized water or tap water. The seeds were incubated at room temperature $\left(25^{\circ} \mathrm{C}\right)$.

\section{Microbial Analysis of Seed Sprouts}

Sprouts after 24, 48, 72, $96 \mathrm{~h}$ of sprouting from $5.0 \mathrm{~g}$ of seeds were suspended in $95 \mathrm{ml}$ sterile water blank. The 
flasks were placed on a rotary shaker for 15 minute and ten fold serial dilutions were prepared. Aliquots of $0.1 \mathrm{ml}$ of appropriate dilutions were spread on plate containing Mac Conkey Agar and Brilliant Green Agar and plates were incubated at $37^{\circ} \mathrm{C}$ for 24 to $48 \mathrm{hrs}$.
The plates were observed after incubation for growth and colony Characteristics. Number of different colonies appearing on the plates was counted and number of bacteria present on each sprout was calculated as follows

\section{No. of Bacteria per Sprout $=\underline{\text { Number of colonies } \times \text { dilution factor } \times 0.1}$}

\section{Cultural Characterization}

The colonies were observed for their color, texture, outline, opacity, pigmentation etc and different type of colonies appearing on all the three media were counted.

\section{Morphological Characterization}

The colonies were picked and processed for Gram staining technique to differentiate between Gram positive and Gram negative bacteria, shape and arrangement of cells.

\section{Media Composition}

Different types of media used in the study were Mac Conkey Agar, Brilliant Green Agar, Baired Parker's Agar etc., which were sterilized by autoclaving at $121^{\circ} \mathrm{C}$ for 20 minute at $15 \mathrm{lbs}$ psi.

Mac Conkey Agar Medium (pH- 7.4) ${ }^{11}$

$\begin{array}{ll}\text { Ingredients } & \text { Amount } \\ \text { Peptone } & 5.0 \\ \text { Lactose } & 10.0 \\ \text { Bile salt } & 5.0 \\ \text { Sodium chloride } & 5.0 \\ \text { Neutral red } & 0.075 \\ \text { Agar } & 15.0\end{array}$

Brilliant Green Agar Medium (pH- 6.9) ${ }^{12}$

Ingredients Amount (g/l)

Lactose $\quad 10.0$

Sucrose $\quad 10.0$

Peptone $\quad 5.0$

Sodium chloride 5.0

Phenol red $\quad 0.08$

Brilliant green $\quad 0.0125$

Agar 20.0

Baired Parker's Medium (pH-7.0) ${ }^{13}$

\section{Ingredients}

Amount (g/ l)

Casein enzyme hydrolysate 10.0

Beef extract

Yeast extract

Glycine

Sodium pyruvate

Lithium chloride

Agar

Number of seeds

Dissolve all the components in $950 \mathrm{ml}$ distilled water sterilize by autoclaving and cool at $50^{\circ} \mathrm{C}$.

\section{MORPHOLOGICAL AND BIOCHEMICAL IDENTIFICATION}

Some of the colonies from different sample and media were picked and purified by streak plate method and ensured by microscopic examination that all the isolates were pure. The bacterial isolates were identified based on the following biochemical tests:

Staphylococcus aureus: Catalase, Coagulase, Sugar fermentation, Salt tolerance, Phosphatase tests.

Salmonella, Klebsiella, E.coli: IMViC, TSI, Urease, Sugar fermentation.

\section{IMViC (Inddole, Methyl red, Vogues-Proskauer, Citrate Test)}

The IMViC tests are designed to differentiate gram negative intestinal bacilli (family enterobacteriaceae) particularly E .coli, Enterobacter, Klebsiella group on the basis of their biochemical properties and enzymatic reactions in the presence of specific substrate. These tests were carried out as follows:

\section{a) Idole Test}

Tryptophan an essential amino acid is oxidized by some bacteria by the enzyme tryptophanase resulting in the formation of indole, pyruvic acid and ammonia. The reaction is detected by adding Kovac's reagent which produce a layer of cherry red colour.

\section{b) Methyl Red Test}

The methyl red test is quantitative test for acid production requiring positive organism to produce strong acid from glucose through the mixed acid fermentation pathway. The $\mathrm{pH}$ indicator dye methyl red changes the colour of the inoculated Methyl Red \& Vogues-Proskauer broth with test organism.

\section{c) Voges - Proskauer Test}

The purpose of Voges-Proskauer is to determine whether an organism can produce acetyl methyl carbinol (acetoin) from fermentation of glucose. In the presence of atmospheric oxygen and alkali (4o\% potassium hydroxide), the small amount of acetyl methyl carbinol present in the medium is converted to diacetyl which react with the peptone of the broth to produce a red colour.

\section{d) Citrate Utilization Test}

The citrate utilization test is to differentiate among enteric bacteria on the basis of their ability to utilize 
/ferment citrate as the sole carbon source. The utilization of citrate depends on the presence of citrase that breaks citrate to oxaloacetic acid and acetic acid. These are later converted into pyruvic acid and carbon dioxide. The $\mathrm{CO}_{2}$ combines with sodium and water to form sodium carbonate an alkaline product which changes the colour of Simmon Citrate Agar slants from green to blue after incubation for $24-48 \mathrm{~h}$ at $37^{\circ} \mathrm{C}$.

\section{TSI Agar Test}

Triple sugar iron agar medium is composed of three sugars i.e. lactose, sucrose and small amount of glucose, iron (ferrous sulphate) and phenol red as indicator. The indicator is employed for the detection of fermentation of sugars indicated by the change in colour of the medium due to the production of organic acid and hydrogen sulphide gas. If an organism ferments any of three sugars or any combination of them, the medium will become yellow due to acid production. The tubes containing TSI agar slants were inoculated with test culture and incubated at $37^{\circ} \mathrm{C}$. The tubes were observed the growth and change in colour after 24- $48 \mathrm{hrs}$.

\section{Urease Test}

The urease a hydrolytic enzyme excreted by some microorganisms attack the carbon and nitrogen bond of amide compounds with the liberation of ammonia. It is useful diagnostic test for identifying bacteria especially to distinguish Proteus from the gram negative pathogens. The presence of urease shows red colour and for no urease it is yellow colour.

\section{Catalase Tests}

Catalase degrades hydrogen peroxide in the bacterial cell before it can do any damage to the bacterial cell. Production of the enzyme catalase can be demonstrated by adding hydrogen peroxide to colonies of bacteria. If catalase is present it is indicated by the presence of free gas bubbles. If catalase is absent no gas bubbles will be seen.

\section{Cogulase Test}

The enzyme cogulase produced by $S$. aureus is a key feature of pathogenic $S$. aureus. The enzyme causes coagulation of blood allowing the organism to wall its infection off from the host's protective mechanism rather effectively. Coagulase is a protein having a prothrombin like activity capable of converting fibrinogen into fimbrin which results in the formation of visible clot.

\section{a) Slide Test}

- The colonies of test organism were picked and emulsified with the drops of saline on a glass slide.

- A drop of serum was added to the bacterial suspension and observed for the clumping of the bacterial suspension.

b) Tube Test

- An aliquote of $0.5 \mathrm{ml}$ of serum in a tube and approximately 5.0 drops of overnight broth culture grown in a test tube were added.
- The tubes were incubated at $37^{\circ} \mathrm{C}$ for $24 \mathrm{hrs}$ and observed the clot formation by gently tilting the tube.

\section{Phosphatase Test}

Staphylococcus aureus produces an enzyme which can split phosphate with the help of enzyme called as phosphatase. Cogulase positive S.aureus give positive phosphatase test. While cogulase negative Staphylococci and Micrococci are usually phosphatase negative.

\section{Glucose Fermentation Test}

Staphylococcus aureus are fermentative capable for producing acid from glucose and mannitol anaerobically. However S. epidermidis is mannitol negative Micrcocci differ from Staphylococci in the fact that they can not ferment glucose and mannitol anaerobically.

\section{Procedure}

- Inoculated the Baired parker carbohydrate agar slant containing glucose and mannitol as sugars (separately) and bromocresol purple as indicator with the test culture.

- The slants were incubated under anaerobic condition at $37^{\circ} \mathrm{C}$ for 24 to $48 \mathrm{hrs}$.

- Observe the slants after incubation for the colour change from purple to yellow.

\section{RESULT AND DISCUSSION}

In the present study an attempt has been made to examine the microorganisms present in seed sprouts of mung bean. The observations of the experiments conducted are discussed below:

\section{Number of Total Coliforms Present in Mung Bean on Mac Conkey Agar}

Sprouts of mung bean were prepared under normal and aseptic conditions as per details given in material and methods and total number of coliforms were determined by spreading appropriate dilution of each type of sprout on plates containing Mac Conkey Agar medium. The plates were observed for type and number of colonies present after $24 \mathrm{~h}$ of interval of incubation for 4 days.

In mung bean sprouts one type of colonies were observed for three days under aseptic condition in sample A, while in sample B one type of colonies were present till 2 days. There after two distinct types of colonies were found on Mac Conkey Agar in both the samples. However two type of colonies appeared after three two day in sprouts prepared under normal conditions in sample A and B respectively.

Total number of cfu/sprout increased from $1.4 \times 10^{3}$ to $6.7 \times 10^{6}$ in different samples and treatments (Table1). For example total cfu/sprouts in sample A under aseptic conditions were $1.4 \times 10^{3}$ which increased to $2.6-5.2 \times 10^{5}$ in both the samples. Total cfu/sprouts prepared under normal conditions in sample $\mathrm{B}$, however, were found to be higher i.e $6.7 \times 10^{6}$. 
Table 1: Number of Coliforms Present in Mung Bean Sprouts on Mac Conkey Agar Medium (cfu/sprout)

\begin{tabular}{|c|c|c|c|c|c|c|c|}
\hline \multirow[b]{3}{*}{ Sample } & \multirow[b]{3}{*}{ Days } & \multicolumn{3}{|c|}{ Sterilized water } & \multicolumn{3}{|c|}{ Unsterilized water } \\
\hline & & \multicolumn{2}{|c|}{ Types of colonies } & \multirow[b]{2}{*}{ Total count } & \multicolumn{2}{|c|}{ Types of colonies } & \multirow[b]{2}{*}{ Total count } \\
\hline & & $\begin{array}{l}\text { Dark pink } \\
\text { with centred, } \\
\text { flat, small, } \\
\text { circular }\end{array}$ & $\begin{array}{l}\text { Light pink with } \\
\text { centred, } \\
\text { gummy, dome } \\
\text { shaped, } \\
\text { circular, small }\end{array}$ & & $\begin{array}{l}\text { Dark pink } \\
\text { with centred, } \\
\text { flat small, } \\
\text { circular }\end{array}$ & $\begin{array}{l}\text { Light pink with } \\
\text { centred, } \\
\text { gummy, dome } \\
\text { shaped, small, } \\
\text { circular }\end{array}$ & \\
\hline \multirow{5}{*}{ A } & 0 & $1.0 \times 10^{1}$ & $=$ & $1.0 \times 10^{1}$ & $2.5 \times 10^{2}$ & $=$ & $2.5 \times 10^{2}$ \\
\hline & 1 & $1.4 \times 10^{3}$ & - & $1.4 \times 10^{3}$ & $3.5 \times 10^{4}$ & $=$ & $3.5 \times 10^{4}$ \\
\hline & 2 & $2.0 \times 10^{4}$ & - & $2.0 \times 10^{4}$ & $6.8 \times 10^{4}$ & & $6.8 \times 10^{4}$ \\
\hline & 3 & $3.6 \times 10^{4}$ & & $3.6 \times 10^{4}$ & $2.7 \times 10^{5}$ & $1.3 \times 10^{3}$ & $2.7 \times 10^{5}$ \\
\hline & 4 & $2.6 \times 10^{5}$ & $6.5 \times 10^{3}$ & $2.6 \times 10^{5}$ & $3.9 \times 10^{6}$ & $6.9 \times 10^{4}$ & $3.9 \times 10^{6}$ \\
\hline \multirow{5}{*}{ B } & 0 & $2.3 \times 10^{1}$ & 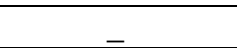 & $2.3 \times 10^{1}$ & $2.9 \times 10^{2}$ & 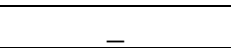 & $2.9 \times 10^{2}$ \\
\hline & 1 & $8.1 \times 10^{3}$ & - & $8.1 \times 10^{3}$ & $3.2 \times 10^{4}$ & & $3.2 \times 10^{4}$ \\
\hline & 2 & $2.2 \times 10^{4}$ & - & $2.2 \times 10^{4}$ & $1.4 \times 10^{4}$ & $1.6 \times 10^{3}$ & $1.5 \times 10^{4}$ \\
\hline & 3 & $3.1 \times 10^{4}$ & $3.2 \times 10^{4}$ & $6.3 \times 10^{4}$ & $4.9 \times 10^{5}$ & $2.2 \times 10^{5}$ & $7.1 \times 10^{5}$ \\
\hline & 4 & $3.6 \times 10^{5}$ & $1.6 \times 10^{5}$ & $5.2 \times 10^{5}$ & $6.5 \times 10^{6}$ & $2.4 \times 10^{5}$ & $6.7 \times 10^{6}$ \\
\hline
\end{tabular}

Types and Number of Bacteria present in Mung Bean Sprouts on Brilliant Green Agar Medium

Number of Salmonella and Shigella spp. present on sprouted seeds was determined by spreading $100 \mu \mathrm{l}$ of appropriate dilution of sprouted seeds on plates containing Brilliant Green Agar medium for four days at an interval of $24 \mathrm{~h}$.

Two distinct creamish, small, gummy and yellow large dome shaped colonies were observed in both the samples of mung bean sprouts prepared under normal as well as aseptic conditions (Table 2). However yellow, large, dome shaped colonies were observed after 48-72 hour of incubation under aseptic conditions.

This type of colonies appeared on Brilliant Green Agar after 24 and $48 \mathrm{~h}$ under normal conditions. The number of $\mathrm{cfu} / \mathrm{ml}$ in sprouted mung beans were found to be $7.9 \times 10^{2}$ and $3.9 \times 10^{3}$ after 24 hour of incubation of sprouts under normal conditions which increased to $7.0 \times 10^{5} \mathrm{cfu} / \mathrm{ml}$ and $7.3 \times 10^{6}$ in sample $A$ and $B$ respectively after $96 \mathrm{~h}$. However in sprouts prepared under aseptic conditions, the number of bacterial count after 96 hours of incubation observed was $5.9 \times 10^{4}$ and $1.3 \times 10^{5} \mathrm{cfu} / \mathrm{ml}$ in sample $A$ and $\mathrm{B}$ respectively.

Table 2: Number of Bacteria Present in Mung Bean Sprouts on Brilliant Green Agar Medium (cfu/ sprout)

\begin{tabular}{|c|c|c|c|c|c|c|c|}
\hline \multirow[b]{3}{*}{ Sample } & \multirow[b]{3}{*}{ Days } & \multicolumn{3}{|c|}{ Sterilized water } & \multicolumn{3}{|c|}{ Unsterilized water } \\
\hline & & \multicolumn{2}{|c|}{ Types of colonies } & \multirow[b]{2}{*}{$\begin{array}{l}\text { Total } \\
\text { count }\end{array}$} & \multicolumn{2}{|c|}{ Types of colonies } & \multirow[b]{2}{*}{ Total count } \\
\hline & & $\begin{array}{l}\text { Cream, small, } \\
\text { circular, without } \\
\text { centred, slightly } \\
\text { gummy raised }\end{array}$ & $\begin{array}{l}\text { Yellow, large, } \\
\text { gummy, dome } \\
\text { shaped, circular }\end{array}$ & & $\begin{array}{l}\text { Cream, small, } \\
\text { circular, without } \\
\text { centred, slightly } \\
\text { gummy raised }\end{array}$ & $\begin{array}{l}\text { Yellow, large, } \\
\text { gummy, dome } \\
\text { shaped, } \\
\text { circular }\end{array}$ & \\
\hline \multirow{5}{*}{ A } & 0 & $7.1 \times 10^{1}$ & - & $7.1 \times 10^{1}$ & $7.1 \times 10^{1}$ & $7.3 \times 10^{0}$ & $7.8 \times 10^{1}$ \\
\hline & 1 & $7.9 \times 10^{2}$ & & $7.9 \times 10^{2}$ & $1.1 \times 10^{3}$ & $4.8 \times 10^{3}$ & $5.9 \times 10^{3}$ \\
\hline & 2 & $6.5 \times 10^{3}$ & $2.4 \times 10^{3}$ & $8.9 \times 10^{3}$ & $3.9 \times 10^{4}$ & $1.0 \times 10^{4}$ & $4.9 \times 10^{4}$ \\
\hline & 3 & $1.5 \times 10^{3}$ & $1.0 \times 10^{4}$ & $1.1 \times 10^{4}$ & $8.1 \times 10^{4}$ & $2.5 \times 10^{3}$ & $8.3 \times 10^{4}$ \\
\hline & 4 & $4.8 \times 10^{4}$ & $1.1 \times 10^{4}$ & $5.9 \times 10^{4}$ & $6.5 \times 10^{3}$ & $9.8 \times 10^{4}$ & $7.0 \times 10^{5}$ \\
\hline \multirow{5}{*}{$\mathrm{B}$} & 0 & $2.5 \times 10^{1}$ & - & $2.5 \times 10^{1}$ & $6.3 \times 10^{1}$ & 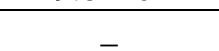 & $6.3 \times 10^{1}$ \\
\hline & 1 & $4.3 \times 10^{2}$ & - & $4.3 \times 10^{2}$ & $2.5 \times 10^{3}$ & & $2.5 \times 10^{3}$ \\
\hline & 2 & $8.4 \times 10^{3}$ & - & $8.4 \times 10^{3}$ & $3.8 \times 10^{4}$ & $1.2 \times 10^{4}$ & $5.0 \times 10^{4}$ \\
\hline & 3 & $2.5 \times 10^{4}$ & $3.9 \times 10^{3}$ & $2.8 \times 10^{4}$ & $1.3 \times 10^{4}$ & $6.5 \times 10^{4}$ & $7.8 \times 10^{4}$ \\
\hline & 4 & $1.1 \times 10^{5}$ & $2.4 \times 10^{4}$ & $1.3 \times 10^{5}$ & $9.1 \times 10^{4}$ & $7.3 \times 10^{6}$ & $7.3 \times 10^{6}$ \\
\hline
\end{tabular}

Types and Number of Bacteria Present in Mung bean Sprouts on Baired Parker's Medium

Number of Staphylococcus aureus present on sprouted seeds was determined by spreading $100 \mu$ l of appropriate dilution of sprouted seeds on plates containing Baired Parker's Medium for 4 days at an interval of 24 hours.

In mung bean sprouts dark black, small, circular, flat colonies were observed under normal as well as aseptic condition. Total number of cfu/sprout increased from $1.8 \times 10^{1}$ to $2.0 \times 10^{3}$ in different sample and treatment (Table 3). For example total cfu/ sprouts in sample A under aseptic conditions were $1.8 \times 10^{1}$ which increased to $4.5 \times 10^{3}$ while total cfu/sprout under normal condition in sample B was found to be high i.e $2.0 \times 10^{3}$ 
Table 3: Number of Bacteria Present in Mung Bean Sprouts on Baired Parker's Medium (cfu/ sprout)

\begin{tabular}{|c|c|c|c|c|c|c|c|}
\hline \multirow[b]{3}{*}{ Sample } & \multirow[b]{3}{*}{ Days } & \multicolumn{3}{|c|}{ Sterilized water } & \multicolumn{3}{|c|}{ Unsterilized water } \\
\hline & & \multicolumn{2}{|c|}{ Types of colonies } & \multirow[b]{2}{*}{ Total count } & \multicolumn{2}{|c|}{ Types of colonies } & \multirow[b]{2}{*}{ Total count } \\
\hline & & $\begin{array}{l}\text { Dark black, } \\
\text { small, circular, } \\
\text { flat }\end{array}$ & $\begin{array}{l}\text { Light grey, } \\
\text { large, gummy, } \\
\text { circular }\end{array}$ & & $\begin{array}{l}\text { Dark black, } \\
\text { small, circular, } \\
\text { flat }\end{array}$ & $\begin{array}{l}\text { Light grey, } \\
\text { large, gummy, } \\
\text { circular }\end{array}$ & \\
\hline \multirow{5}{*}{ A } & 0 & & & & $1.0 \times 10^{1}$ & & $1.0 \times 10^{1}$ \\
\hline & 1 & $1.8 \times 10^{1}$ & - & $1.8 \times 10^{T}$ & $9.0 \times 10^{1}$ & _ & $9.0 \times 10^{\Gamma}$ \\
\hline & 2 & $3.1 \times 10^{2}$ & _ & $3.1 \times 10^{2}$ & $7.2 \times 10^{2}$ & $=$ & $7.2 \times 10^{2}$ \\
\hline & 3 & $2.4 \times 10^{3}$ & - & $2.4 \times 10^{3}$ & $6.5 \times 10^{3}$ & & $6.5 \times 10^{3}$ \\
\hline & 4 & $4.5 \times 10^{3}$ & - & $4.5 \times 10^{3}$ & $9.1 \times 10^{3}$ & - & $9.1 \times 10^{3}$ \\
\hline \multirow{5}{*}{ B } & 0 & $1.0 \times 10^{1}$ & - & $1.0 \times 10^{1}$ & $1.8 \times 10^{1}$ & - & $1.8 \times 10^{\mathrm{I}}$ \\
\hline & 1 & $1.1 \times 10^{2}$ & & $1.1 \times 10^{2}$ & $2.0 \times 10^{2}$ & & $2.0 \times 10^{2}$ \\
\hline & 2 & $4.0 \times 10^{2}$ & - & $4.0 \times 10^{2}$ & $9.8 \times 10^{2}$ & - & $9.8 \times 10^{2}$ \\
\hline & 3 & $7.3 \times 10^{2}$ & & $7.3 \times 10^{2}$ & $1.0 \times 10^{3}$ & & $1.0 \times 10^{3}$ \\
\hline & 4 & $1.3 \times 10^{3}$ & & $1.3 \times 10^{3}$ & $2.0 \times 10^{3}$ & & $2.0 \times 10^{3}$ \\
\hline
\end{tabular}

\section{Morphological and Biochemical Characteristics of Selected Isolates}

List of isolates from different samples of mung bean sprouts picked at different time interval is given in table 4 .

Table 4: List of isolates from mung bean sprouts

\begin{tabular}{|c|c|c|c|}
\hline Sample & Media & Colony characteristics & Code no. \\
\hline \multirow{5}{*}{ A } & \multirow{2}{*}{ Mac Conkey Agar } & Dark pink, flat,small, circular & $\mathrm{I}-\mathrm{A} 1, \mathrm{I}-\mathrm{A} 2, \mathrm{I}-\mathrm{A} 3, \mathrm{I}-\mathrm{A} 4$ \\
\hline & & Light pink with centred, gummy, dome shaped, circular & II -A1 II-A2 II-A3 II-A4 \\
\hline & \multirow[b]{2}{*}{ Brilliant Green Agar } & Cream, small, circular raised & III -A1 III-A2, III-A3, III-A4 \\
\hline & & $\begin{array}{l}\text { Yellow, gummy, large } \\
\text { Dome shaped, circular }\end{array}$ & IV -A1, IV-A2, IV-A3, IV-A4 \\
\hline & Baired Parker's Agar & Dark black, small, circular & $\mathrm{V}-\mathrm{A} 1, \mathrm{~V}-\mathrm{A} 2, \mathrm{~V}-\mathrm{A} 3, \mathrm{~V}-\mathrm{A} 4$ \\
\hline \multirow{5}{*}{ B } & \multirow{2}{*}{ Mac Conkey Agar } & Dark pink, flat, small, circular & $\mathrm{I}-\mathrm{B} 1, \mathrm{I}-\mathrm{B} 2, \mathrm{I}-\mathrm{B} 3, \mathrm{I}-\mathrm{B} 4$ \\
\hline & & Light pink with centred, gummy, dome shaped, circular & II -B1 ,II-B2, II-B3, II-B4 \\
\hline & \multirow[b]{2}{*}{ Brilliant Green Agar } & Cream, small, circular raised & III -B1 ,III-B2, III-B3, III-B4 \\
\hline & & $\begin{array}{l}\text { Yellow, gummy, large } \\
\text { Dome shaped, circular }\end{array}$ & IV -B1 ,IV-B2, IV-B3, IV-B4 \\
\hline & Baired Parker's Agar & Dark black, small, circular & $\mathrm{V}-\mathrm{B} 1, \mathrm{~V}-\mathrm{B} 2, \mathrm{~V}-\mathrm{B} 3, \mathrm{~V}-\mathrm{B} 4$ \\
\hline
\end{tabular}

All these cultures were transferred to nutrient agar slants and stored for further use. Some of the morphological and biochemical characteristic of these isolates were examined. Twelve isolates from Mac Conkey agar plates, four isolates from Brilliant Green Agar medium plates and seven isolates from Baired Parker's medium were picked and examined for morphological and biochemical characteristics as given in table 5, 6, 7 .

Table 5: Morphological and Biochemical Characteristics of Selected Isolates on Mac Conkey Agar

\begin{tabular}{|c|c|c|c|c|c|c|c|c|c|c|c|c|c|}
\hline \multirow{3}{*}{$\begin{array}{c}\text { Sampl } \\
\text { e no. }\end{array}$} & \multicolumn{4}{|c|}{ Morphological Characterstics } & \multicolumn{8}{|c|}{ Biochemical Characteristics } & \multirow{3}{*}{$\begin{array}{c}\text { Suspecte } \\
\text { d } \\
\text { Miroorga } \\
\text {-nism }\end{array}$} \\
\hline & \multirow{2}{*}{$\begin{array}{l}\text { Cell shape } \\
\text { arrangeme } \\
\text { nt }\end{array}$} & \multirow{2}{*}{$\begin{array}{c}\text { Gram } \\
\text { reactio } \\
n\end{array}$} & \multirow{2}{*}{$\begin{array}{c}\text { Spore } \\
\text { formati } \\
\text { on }\end{array}$} & \multirow{2}{*}{$\begin{array}{c}\text { Motilit } \\
\mathbf{y}\end{array}$} & \multicolumn{4}{|c|}{ IMViC } & \multirow[b]{2}{*}{ TSI } & \multirow[b]{2}{*}{$\mathbf{H}_{2} \mathrm{~S}$} & \multirow{2}{*}{$\begin{array}{c}\text { Glucose } \\
\text { ferment- } \\
\text { ation }\end{array}$} & \multirow[b]{2}{*}{$\begin{array}{c}\text { Urea } \\
\text { se }\end{array}$} & \\
\hline & & & & & $\begin{array}{c}\text { Indol } \\
\mathbf{e}\end{array}$ & $\begin{array}{c}\mathbf{M} \\
\mathbf{R}\end{array}$ & $\mathbf{V P}$ & Citrae & & & & & \\
\hline I-A3 & Rod shaped & - & - & + & + & + & _ & _ & $\mathrm{A} / \mathrm{A}$ & _ & + & - & E.coli \\
\hline I-A4 & Rod shaped & - & - & + & + & + & - & - & $\mathrm{A} / \mathrm{A}$ & 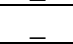 & + & - & E.coli \\
\hline I-B2 & Rod shaped & 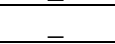 & - & + & + & + & - & - & $\mathrm{A} / \mathrm{A}$ & 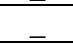 & + & 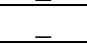 & E.coli \\
\hline I-B3 & Rod shaped & 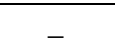 & - & + & + & + & - & - & $\mathrm{A} / \mathrm{A}$ & - & + & - & E.coli \\
\hline II-A1 & Rod shaped & - & - & - & - & - & - & - & $\mathrm{A} / \mathrm{A}$ & - & + & + & Klebsiella \\
\hline II-A2 & Rod shaped & - & - & - & - & 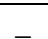 & + & + & $\mathrm{A} / \mathrm{A}$ & - & + & + & Klebsiella \\
\hline II-A3 & Rod shaped & - & - & - & - & - & + & + & $\mathrm{A} / \mathrm{A}$ & 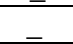 & + & + & Klebsiella \\
\hline II-A4 & Rod shaped & 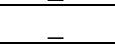 & 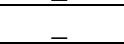 & 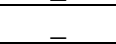 & - & - & + & + & $\mathrm{A} / \mathrm{A}$ & - & + & + & Klebsiella \\
\hline II-B1 & Rod shaped & - & - & - & - & - & + & + & $\mathrm{A} / \mathrm{A}$ & - & + & + & Klebsiella \\
\hline II-B2 & Rod shaped & - & - & - & - & - & + & + & $\mathrm{A} / \mathrm{A}$ & - & + & + & Klebsiella \\
\hline II-B3 & Rod shaped & - & - & - & - & - & + & + & $\mathrm{A} / \mathrm{A}$ & $=$ & + & + & Klebsiella \\
\hline
\end{tabular}


Table 6: Marphological and Biochemical Characteristics of Selected Isolates on Brilliant Green Agar Medium

\begin{tabular}{|c|c|c|c|c|c|c|c|c|c|c|c|c|c|}
\hline \multirow{2}{*}{$\begin{array}{c}\text { Sam } \\
\text { ple } \\
\text { no. }\end{array}$} & $\begin{array}{c}\text { Mell } \\
\text { shape } \\
\text { arrangem } \\
\text { ent }\end{array}$ & $\begin{array}{c}\text { Gram } \\
\text { reacti } \\
\text { on }\end{array}$ & $\begin{array}{c}\text { Spore } \\
\text { formati } \\
\text { on }\end{array}$ & $\begin{array}{c}\text { Motili } \\
\text { ty }\end{array}$ & $\begin{array}{c}\text { Indo } \\
\text { le }\end{array}$ & $\begin{array}{c}\text { M } \\
\text { R }\end{array}$ & $\begin{array}{c}\text { V } \\
\mathbf{P}\end{array}$ & $\begin{array}{c}\text { Citra } \\
\text { te }\end{array}$ & TSI & $\begin{array}{c}\mathbf{H}_{2} \\
\mathbf{S}\end{array}$ & $\begin{array}{c}\text { Glucose } \\
\text { fermentat } \\
\text { ion }\end{array}$ & $\begin{array}{c}\text { Urea } \\
\text { se }\end{array}$ & $\begin{array}{c}\text { Suspect } \\
\text { ed } \\
\text { Micro- } \\
\text { organis } \\
\text { m }\end{array}$ \\
\hline $\begin{array}{c}\text { III- } \\
\text { A1 }\end{array}$ & $\begin{array}{c}\text { Rod } \\
\text { shaped }\end{array}$ & - & - & + & - & + & - & + & $\begin{array}{c}\text { Alk/ } \\
\text { A }\end{array}$ & + & + & - & $\begin{array}{c}\text { Salmone } \\
\text { lla }\end{array}$ \\
\hline $\begin{array}{c}\text { III- } \\
\text { A4 }\end{array}$ & $\begin{array}{c}\text { Rod } \\
\text { shaped }\end{array}$ & - & - & + & - & + & - & + & $\begin{array}{c}\text { Alk/ } \\
\text { A }\end{array}$ & + & + & - & $\begin{array}{c}\text { Salmone } \\
\text { lla }\end{array}$ \\
\hline $\begin{array}{c}\text { III- } \\
\text { B3 }\end{array}$ & $\begin{array}{c}\text { Rod } \\
\text { shaped }\end{array}$ & - & - & + & - & + & - & + & $\begin{array}{c}\text { Alk/ } \\
\text { A }\end{array}$ & + & + & - & $\begin{array}{c}\text { Salmone } \\
\text { lla }\end{array}$ \\
\hline $\begin{array}{c}\text { III- } \\
\text { B2 }\end{array}$ & $\begin{array}{c}\text { Rod } \\
\text { shaped }\end{array}$ & - & - & - & - & + & - & - & $\begin{array}{c}\text { Alk/ } \\
\text { A }\end{array}$ & - & - & - & Shigella \\
\hline
\end{tabular}

Table 7: Marphological and Biochemical Characteristics of Selected Isolates on Baired Parker's Medium

\begin{tabular}{|c|c|c|c|c|c|c|c|c|c|c|}
\hline \multirow[b]{2}{*}{$\begin{array}{l}\text { Samp } \\
\text { le no. }\end{array}$} & \multicolumn{4}{|c|}{ Morphological Characteristics } & \multicolumn{5}{|c|}{ Biochemical Characteristics } & \multirow[b]{2}{*}{$\begin{array}{l}\text { Suspected } \\
\text { Microorgan } \\
\quad \text { ism }\end{array}$} \\
\hline & $\begin{array}{c}\text { Cell } \\
\text { shape } \\
\text { arrangem } \\
\text { ent }\end{array}$ & $\begin{array}{c}\text { Gram } \\
\text { reacti } \\
\text { on }\end{array}$ & $\begin{array}{c}\text { Spore } \\
\text { formati } \\
\text { on }\end{array}$ & $\begin{array}{c}\text { Motili } \\
\text { ty }\end{array}$ & $\begin{array}{l}\text { Catala } \\
\text { se test }\end{array}$ & $\begin{array}{l}\text { Coagul } \\
\text { ase test }\end{array}$ & $\begin{array}{c}\text { Salt } \\
\text { toleran } \\
\text { ce test }\end{array}$ & $\begin{array}{c}\text { Phosphat } \\
\text { ase } \\
\text { Test }\end{array}$ & $\begin{array}{c}\text { Glucose } \\
\text { fermentat } \\
\text { ion test }\end{array}$ & \\
\hline VA-1 & $\begin{array}{l}\text { Cocci in } \\
\text { bunches }\end{array}$ & + & - & - & + & + & + & + & + & S.aureus \\
\hline VA-2 & $\begin{array}{l}\text { Cocci in } \\
\text { bunches }\end{array}$ & + & - & - & + & + & + & + & + & S.aureus \\
\hline VA-3 & $\begin{array}{l}\text { Cocci in } \\
\text { bunches }\end{array}$ & + & - & - & + & + & + & + & + & S.aureus \\
\hline VA-4 & $\begin{array}{l}\text { Cocci in } \\
\text { bunches }\end{array}$ & + & - & - & + & + & + & + & + & S.aureus \\
\hline VB-1 & $\begin{array}{l}\text { Cocci in } \\
\text { bunches }\end{array}$ & + & - & - & + & + & + & + & + & S.aureus \\
\hline VB-2 & $\begin{array}{l}\text { Cocci in } \\
\text { bunches }\end{array}$ & + & - & - & + & + & + & + & + & S.aureus \\
\hline VB-4 & $\begin{array}{l}\text { Cocci in } \\
\text { bunches }\end{array}$ & + & - & - & + & + & + & + & + & S.aureus \\
\hline
\end{tabular}

\section{SUMMERY AND CONCLUSION}

The present study was conducted to examine the microorganisms present on the surface of mung bean sprouts prepared under laboratory conditions using sterilized and unsterilized water.

$>$ The number of microorganisms present on the surface of sprouts was determined by suspending the sprouts in sterilized distilled water and spreading the appropriate dilution on three different types of media ie Mc Conkey Agar, Brilliant Green Agar and Baired Parker's medium.

$>$ The initial number of coliforms present on seed surface was low but it increased from $1.0 \times 10^{1}$ cfu/sprout to $6.7 \times 10^{6} \mathrm{cfu} /$ sprout after 4 days of incubation on Mc Conkey Agar medium.

$>$ The number of microorganisms was found to be varying from $5.9 \times 10^{4}$ to $7.3 \times 10^{6} \mathrm{cfu} /$ sprout on Brilliant Green Agar after 4 days of incubation whereas on Baired Parker's medium the number of microorganisms varied from $1.3 \times 10^{3}$ to $9.1 \times 10^{3}$ cfu/sprout.

$>$ Twenty three number of isolates were picked from different samples on three different types of media and purified for morphological and biochemical characterization. They were found to belong to Escherichia coli, Klebsiella, Salmonella, Shigella and Staphylococcus aureus.

$>$ Thus, care should be taken in the consumption of the raw sprouts irrespective of their source i.e. whether prepared at home or procured from the retail market.

\section{ACKNOWLEDGEMENT}

The authors are very thankful to the Head, Department of Microbiology, Sardar Bhagwan Singh Post Graduate Institute of Biomedical Sciences and Research, Balawala, Dehradun for providing permission and necessary help during research work. 


\section{REFERENCE}

1. Augustin, J. and B. P. Klein 1983. Nutrient content of sprouted wheat and selected legumes. Cereal Foods World, 28: 58-361.

2. Fordham, J. R., C. E. Wells, and L. H. Chen 1975. Sprouting of seeds and nutrient composition of seeds and sprouts. J. Food Sci., 40: 552-556.

3. Kylen, A. M and R. M. McCready 1975. Nutrients in seeds and sprouts of alfalfa, lentils, mung beans and soybeans. J. Food Sci. 40: 1008-1009.

4. Chavan, J. K. and S. S. Kadam 1989. Nutritional improvement of cereals by sprouting CRC Crit. Rev. Food Sci. Nutr. 28:401437.

5. http://www.cdc.gov/foodborneoutbreaks/us_outb/fbo2003/Outb reak_Linelist_Final. (Accessed on July, 2011)

6. Buck. P., K. Grimsrud, J. Waters, R. Cardinal, J. Talbot and C. Anand 1998. Would you like a little Salmonella with your sandwich? In Proceedings and abstracts of the 47th Annual Epidemic Intelligence Service Conference, Atlanta, GA, April p13-17.

7. Harb, J., S. Isaacs and M. Fyfe 2003. Outbreak of Salmonella enteritidis phage type $11 \mathrm{~B}$ in the providences of Alberta and Saskatchewan. Epidemiol. Infect., 128: 523-527.
8. Proctor, M.E., Marge Hamacher, Mary Lou Tortorello, John R. Archer, and Jeffrey P. Davis, 2001. Multistate outbreak of Salmonella serovar Muenchen infections associated with alfalfa sprouts grown from seeds pretreated with calcium hypochlorite. J. Clin. Micorbiol. 39: 3461-3465.

9. Bari, M. L., D. Nei, K. Enomoto, S. Todoriki and S. Kawamoto 2009. Combination treatments for killing Escherichia coli O157:H7 on alfalfa, radish, broccoli, and mung bean seeds. $J$. Food Prot. 72: 631-636.

10. Himathongkham, S., S. Nuanualsuwan, H. Riemann and D. O. Cliver, 2001. Reproduction of Escherichia coli 0157:H7 and Salmonella typhimurium in artificially contaminated alfalfa seeds and mung beans by fumigation with ammonia. J. Food Prot. 64: 1817-1819.

11. www.himedialabs.com/TD/M081B.pdf (Accessed on February, 2012).

12. www.himedialabs.com/TD/M016.pdf (Accessed on February, 2012).

13. www.himedialabs.com/TD/M043.pdf (Accessed on February, 2012). 